\title{
Correction to: The Local Mission: Improving Access to Surgical Care in Middle-Income Countries
}

\author{
Eric S. Nagengast ${ }^{1,2,3}$ (1) Naikhoba C. O. Munabi ${ }^{1,2,3} \cdot$ Meredith Xepoleas $^{2,3} \cdot$ Allyn Auslander $^{2,4}$. \\ William P. Magee III ${ }^{1,2,3,5} \cdot$ David Chong $^{6}$
}

Published online: 12 February 2021

(C) The Author(s) 2021

\section{Correction to: World J Surg \\ https://doi.org/10.1007/s00268-020-05882-8}

The article "The Local Mission: Improving Access to Surgical Care in Middle-Income Countries", written by Nagengast et al., was originally published electronically on the publisher's internet portal on January 2, 2021, without open access. With the author(s)' decision to opt for Open Choice the copyright of the article changed on January 26, 2021 to (c) The Author(s) 2021 and the article is forthwith distributed under a Creative Commons Attribution.

The original article can be found online at https://doi.org/10.1007/ s00268-020-05882-8.

Eric S. Nagengast

Eric.nagengast@med.usc.edu

1 Division of Plastic and Reconstructive Surgery, Keck School of Medicine, University of Southern California, 1510 San Pablo St, Suite 415, Los Angeles, CA 90033, USA

2 Division of Plastic and Maxillofacial Surgery, Children's Hospital of Los Angeles, 4650 Sunset Blvd, Los Angeles, CA 90027, USA

3 Operation Smile Inc., 3641 Faculty Boulevard, Virginia Beach, VA 23453, USA

4 Department of Preventive Medicine, Keck School of Medicine of the University of Southern California, Los Angeles, CA, USA

5 Division of Plastic and Reconstructive Surgery, Shriners Hospital for Children, 909 S Fair Oaks Ave, Pasadena, CA 91105, USA

6 Department of Plastic and Maxillofacial Surgery, Royal Children's Hospital, Flemington Rd, Melbourne, Australia
Open Access This article is licensed under a Creative Commons Attribution 4.0 International License, which permits use, sharing, adaptation, distribution and reproduction in any medium or format, as long as you give appropriate credit to the original author(s) and the source, provide a link to the Creative Commons licence, and indicate if changes were made. The images or other third party material in this article are included in the article's Creative Commons licence, unless indicated otherwise in a credit line to the material. If material is not included in the article's Creative Commons licence and your intended use is not permitted by statutory regulation or exceeds the permitted use, you will need to obtain permission directly from the copyright holder. To view a copy of this licence, visit http://creativecommons.org/licenses/by/4.0/.

Publisher's Note Springer Nature remains neutral with regard to jurisdictional claims in published maps and institutional affiliations. 